\title{
Assessment of Farmer's Practices on the Rubber Nursery Management Using Growing Medium and Varietal Selection in Mon State
}

\author{
Khaing Hninn Soe1, Kyaw Ngwe, Yinn Mar Soe1, Kyaw Kyaw Win², Aung Naing 0o³ \\ ${ }^{1}$ Department of Soil and Water Science, Yezin Agricultural University, Naypyitaw, Myanmar \\ ${ }^{2}$ Pro Rector (Admin.) Office, Yezin Agricultural University, Naypyitaw, Myanmar \\ ${ }^{3}$ Phyu Campus, Yezin Agricultural University, Naypyitaw, Myanmar \\ Email: khninnsoe@gmail.com
}

How to cite this paper: Soe, K.H., Ngwe, K., Soe, Y.M., Win, K.K. and Oo, A.N. (2022) Assessment of Farmer's Practices on the Rubber Nursery Management Using Growing Medium and Varietal Selection in Mon State. Agricultural Sciences, 13, 307-320. https://doi.org/10.4236/as.2022.133021

Received: January 28, 2022

Accepted: February 27, 2022

Published: March 2, 2022

Copyright (C) 2022 by author(s) and Scientific Research Publishing Inc. This work is licensed under the Creative Commons Attribution International License (CC BY 4.0).

http://creativecommons.org/licenses/by/4.0/

(c) (i) Open Access

\begin{abstract}
Rubber is an economically important perennial crop in Myanmar for latex production. As the rubber plantation area increases yearly, the requirement of vigorous rubber seedlings for its establishment plays a central role. The success of rubber plantations depends on some farming practices such as using different compost or other materials in the potting soil-medium, varietal selection for stock and scion in the budding process, and fertilizer application methods. The objective of this study was to assess the farmer's practices in the establishment of rubber nurseries in mostly rubber planted areas in Myanmar. The survey interviewed 60 respondents from three townships in Mon State, namely Mudon, Kyaikmaraw, and Thanbyuzayat. The response data were analyzed through the descriptive method. This survey exposed the potentially active operators (middle age of 30 - 60 years) in rubber nursery production. Local experienced farmers usually raised the budded seedlings with $15 \mathrm{~cm} \times 23 \mathrm{~cm}$ polyethylene bag in all study regions. Most farmers selected multi-clonal seed for stock and BPM 24 for scion according to the local market demand and high latex yield. All survey areas used both organic and inorganic fertilizers for nutrient management. Compost is a chief component of growing medium in their nursery production. However, making compost and high demand of the compost were local constraints. Therefore, this survey suggested improving the proper composting method for rubber nursery establishment.
\end{abstract}

\section{Keywords}

Compost, Farmers' Practices, Nutrient Management, Varietal Selection 


\section{Introduction}

Nowadays, ASEAN is leading to the top of the world's rubber production. Myanmar, which belongs to ASEAN countries and also bounders with the southern part of Thailand, emphasizes extending rubber plantations for latex production. Historically, rubber plantations had introduced into Myanmar in 1876. However, the commercial production of rubber started in 1909 with a plantation area of 4000 hectares [1]. Currently, rubber production is still expanding and the total cultivated area is standing about 660,000 ha with 269,000 MT production [2]. Thus, rubber production in Myanmar is economically essential, and it recognizes as the second most agricultural export crop after beans and pulses [3].

Mon State lies in the South-Eastern region of Myanmar, including two districts with ten townships. Rubber is mainly grown in this state, and local people from Mudon, Kyaikmaraw, and Thanbyuzayat townships earn a lot of money from its production, including nursery sales [4]. Those people ( $42 \%$ of the rubber growers) are smallholders to participate in the developing rubber production industry [5]. Hence, the study about nursery production provides the main economy of Myanmar for the extension of the rubber plantation.

The selection of well-performed varieties is necessary for the first step of rubber plantation. The commonly used varieties in Mon state are Balai Penelitian Perkebunan Medan-BPM 24, Prang Besar Co-PB 235, PB 260, Rubber Research Institute of Ceylon-RRIC 100, and RRIM 717 from the Rubber Research Institute of Malaysia [1]). In the rubber nursery, seedlings are usually raised with three methods namely, field budded seedling, budded stump seedling, and polybag budded seedling. As polybag budded seedlings with two to three whorls of fully expanded leaves give the best growth in field plantation, this method is widely used in areas of rubber establishment [6]. In budding, the selection of scions and stocks characterizes successful rubber productions. Moreover, wellcompost in the potting media of polybag budded seedling modifies the plant growth and determines its nutrient availability. Using the improper growing media attributes to the poor performance of rubber seedlings and contributes to the inferior growth and yield of rubber due to roots \& shoots' damage and dying plants [7]. Under soil fertility management, proper amendments of soil provide vigorous seedlings and increase latex production in field plantations. Thus, appropriate soil fertility management in the nursery is critical [8].

As the rubber plantation area in Myanmar is yearly increases, it is necessary to supply vigorous rubber seedlings for the plantation. According to the statistics [9], Mon state produced 1,080,000 rubber seedlings and distributed them to local and other regions. Nationally, for the success of rubber plantations, it is still necessary to assess the rubber nursery management practices and economic constraints [5]. However, some indicators to predict farming practices and nutrient management in detail, such as the use of compost or other materials in the potting media, selection of rubber varieties concerned with stock, and scion, bud- 
ding process, and fertilizer application methods, were lacking.

Thus, the objective of this survey was to assess the farmer's practices in the establishment of rubber nurseries using compost for growing media and varietal selection in mostly rubber cultivated areas in Myanmar.

\section{Materials and Methods}

\subsection{Description of the Study Site Profile}

This survey was conducted in Mon State. Mon State is situated on the western coast of the South-Eastern part of Myanmar. The total area of Mon State is about $12,296 \mathrm{~km}^{2}$, and it is $<1.81$ percent of Myanmar. It is situated in latitude $14^{\circ} 52^{\prime} \mathrm{N}$ to $17^{\circ} 32^{\prime} \mathrm{N}$ and longitude $96^{\circ} 51^{\prime} \mathrm{E}$ to $98^{\circ} 13^{\prime} \mathrm{E}$. Mon State is an administrative division of Myanmar and incorporated with two districts, namely Thaton and Mawlamyine. The former district contains four townships. They are Kyaikhto, Bilin, Thaton, and Paung respectively. The latter district includes six towns, namely Mawlamyine, Chaungzone, Kyaikmaraw, Mudon, Thanbyuzayat, and Ye. The total population is $2,570,375$. This data indicates about $4 \%$ of the total population in Myanmar. The population density was about $209 \mathrm{~km}^{-2}$ in 2018-2019. About $68 \%$ of the people lived in rural areas, and the rest (32\%) lived in urban areas [4]. This value is closer to the Union level of rural-urban distribution in which 70 percent of the population live in rural areas, and 30 percent live in urban areas [10]. According to the Department of Agricultural Land Management \& Statistics [11], the total land allocation of rubber in 2019-2020 was about 660,306 ha in Myanmar, and about $47.4 \%$ (201,410 ha) was the rubber plantation area of Mon state (Table 1). This number is maximum among the rubber growing regions. As rubber is the second most important crop after paddy in Mon state, rubber production is not negligible. Table 2 shows the rubber plantation area of Mon state in 2020-2021. Although Ye planted the largest areas among townships, Mudon, Kyaikmaraw, and Thanbyuzayat townships are the main rubber seedlings producers (Table 3 ).

The climate of Mon State is tropical humid because its location is in the low altitude area zone and near the sea. Temperature fluctuation is narrow there. The rainy season sets at Mid-May, and it ends in September. Based on ten-year data, the average annual precipitation is $5580.9 \mathrm{~mm}$, and this amount covers 153 rainy days.

In 2020 , the maximum temperature $\left(40.4^{\circ} \mathrm{C}\right)$ occurred in May, and the minimum temperature $\left(13.6^{\circ} \mathrm{C}\right)$ in January [9]. We conducted this strategic survey in three townships of Mon state, namely Mudon, Kyaikmaraw (KMR), and Thanbyuzayat (TBZ). These regions locate in latitude $15^{\circ} 27^{\prime} \mathrm{N}$ to $16^{\circ} 7^{\prime} \mathrm{N}$ and longitude $97^{\circ} 34^{\prime} \mathrm{E}$ to $97^{\circ} 9^{\prime} \mathrm{E}$ (Figure 1). The outlines of the study areas were shown in Table 4.

The Mawlamyine district occupies $6084 \mathrm{~km}^{2}$. The total population there is $(1,232,221)$, of which $64.8 \%$ of people $(798,129)$ are lived in rural areas and 
Table 1. Rubber plantation area of Union of Myanmar in 2019-2020.

\begin{tabular}{cccc}
\hline Sr. No. & State/Region & Sown area (ha) & Percent of the Union \\
\hline 1 & Kachin & $33,115.38$ & 5.015 \\
2 & Kayah & 26.72 & 0.004 \\
3 & Kayin & $109,755.47$ & 16.622 \\
4 & Chin & 3.64 & 0.001 \\
5 & Rakhine & $14,439.68$ & 2.187 \\
6 & Mon & $201,410.93$ & 30.503 \\
7 & Shan & $74,764.37$ & 11.323 \\
8 & Yangon & $17,637.65$ & 2.671 \\
9 & Bago & $47,791.90$ & 7.238 \\
10 & Ayeyarwady & $15,008.50$ & 2.273 \\
11 & Mandalay & 46.15 & 0.007 \\
12 & Sagaing & 5074.49 & 0.769 \\
13 & Tanintharyi & $141,231.98$ & 21.389 \\
\hline
\end{tabular}

Source: [11].

Table 2. Rubber plantation area of Mon state in 2020-2021.

\begin{tabular}{cccc}
\hline Sr. No. & State/Region & Sown area (ha) & Percent of the State \\
\hline 1 & Kyaikhto & $14,991.90$ & 7.37 \\
2 & Bilin & 9976.52 & 4.91 \\
3 & Thaton & $19,319.43$ & 9.50 \\
4 & Paung & 7802.43 & 3.84 \\
5 & Mawlwmyine & 900.81 & 0.44 \\
6 & Chaungzone & 2399.19 & 1.18 \\
7 & Kyaikmaraw & $34,163.97$ & 16.81 \\
8 & Mudon & $24,385.43$ & 12.00 \\
9 & Thanbyuzayat & $27,872.47$ & 13.71 \\
10 & Ye & $61,484.21$ & 30.24 \\
\hline
\end{tabular}

Source: [9].

Table 3. Production and distribution of rubber seedlings in Mon state (2020-2021).

\begin{tabular}{cccc}
\hline Sr. No. & Townships & No. of seedlings & Percent of the State \\
\hline 1 & Kyaikhto & 30,000 & 2.98 \\
2 & Bilin & 10,000 & 0.99 \\
3 & Thaton & 10,000 & 0.99 \\
4 & Paung & 50,000 & 4.96 \\
5 & Mawlwmyine & - & - \\
6 & Chaungzone & 8000 & 0.79 \\
7 & Kyaikmaraw & 150,000 & 14.88 \\
8 & Mudon & 500,000 & 49.60 \\
9 & Thanbyuzayat & 200,000 & 19.84 \\
10 & Ye & 50,000 & 4.96 \\
\hline
\end{tabular}

Source: [9]. 
Table 4. Outlines of Kyaikmaraw, Mudon and Thanbyuzayat townships.

\begin{tabular}{llll}
\hline Parameters & Kyaikmaraw & Mudon & Thanbyuzayat \\
\hline Total land area $\left(\mathrm{km}^{2}\right)$ & 1325 & 815 & 823 \\
Population & 195,810 & 190,737 & 170,536 \\
• Males & 92,746 & 89,976 & 81,449 \\
• Females & 103,064 & 100,761 & 89,087 \\
No. of household & 38,888 & 39,312 & 36,234 \\
$\bullet$ Male-headed household (\%) & 71 & 72.4 & 73.9 \\
$\bullet$ Female-headed household (\%) 29 & 27.6 & 26.1
\end{tabular}

Source: [10].

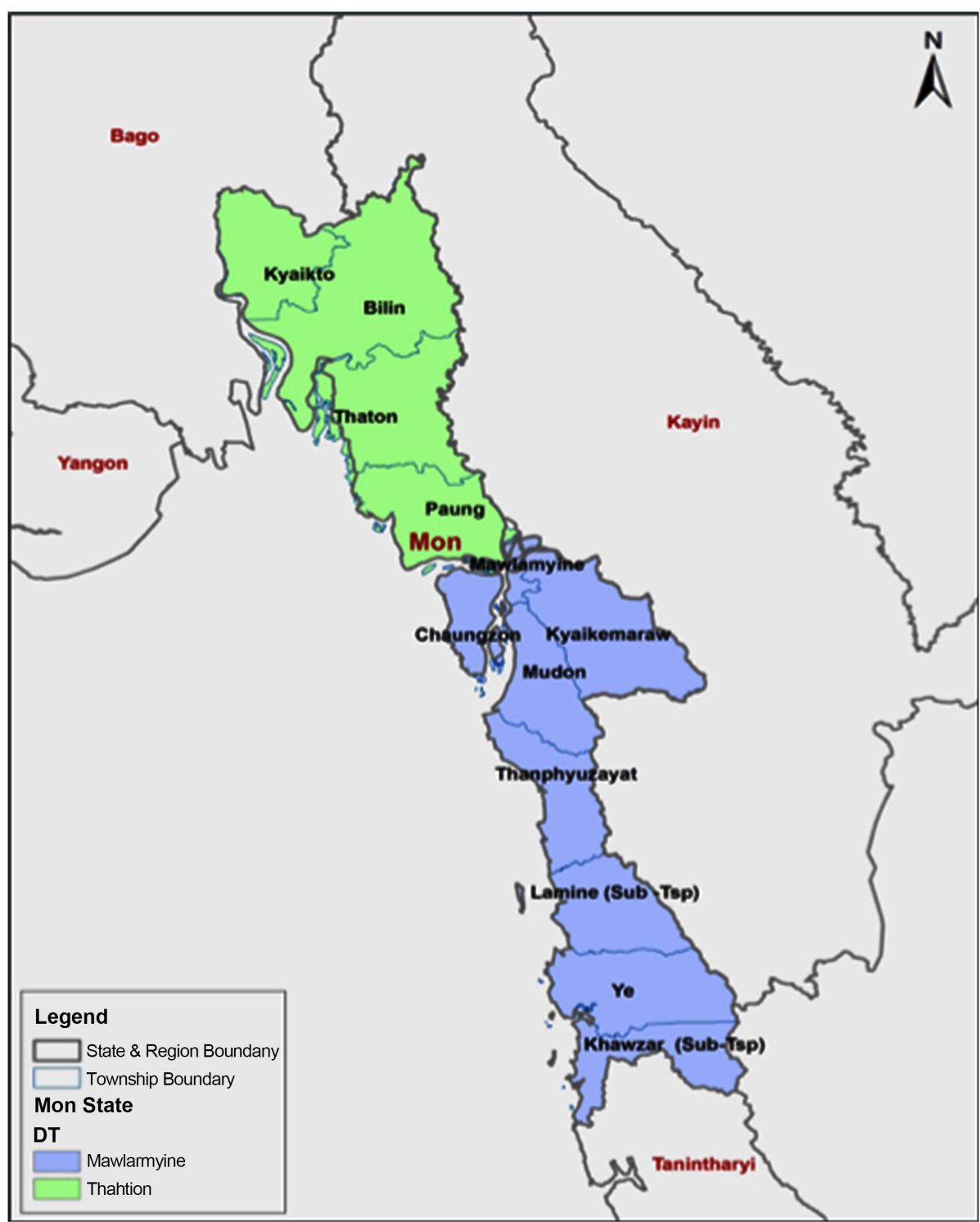

Figure 1. Map of the survey area in Kyaikmaraw, Mudon and Thanbyuzayat townships, Mon State. Source: [10]. 
$35.2 \%(434,092)$ in urban areas. In this district, $57.2 \%$ of the employment to total population were within the economically active age group of 15 - 64 years. Most of them earn money from the agriculture sector [10].

\subsection{Data Collection and Sampling Method}

The survey was conducted in January 2019 by using a simple random sampling method. Firstly, we prepared a well-structured questionnaire to collect the primary data. Then, a total of 60 respondents, including 20 each from three townships, namely Mudon, Kyaikmaraw, and Thanbyuzayat, were personally interviewed. We selected these regions as study areas because of the main production of rubber seedlings. The primary information contained the data of the nursery practice of rubber, use of growing media in the potting soil of rubber nursery, use of rubber variety for stock and scion, the farmer's knowledge of composting concern about the use of raw materials for composting, their composting methods, fertilizer usage for nursery and budding practices. Moreover, we collected demographic data such as age, educational status, family size, and farming experience of the growers. Lastly, we also gathered the secondary data from published and official records of the Ministry of Agriculture, Livestock and Irrigation (MOALI), Department of Agriculture (DOA), Mon State, and other related publications are used to format this paper and style the text.

\subsection{Data Analysis Methods}

All collected data were analyzed using Statistical Packages for Social Sciences (SPSS 16.0) and Microsoft Excel programs. We characterized the demographic data, selection of the variety, use of compost, and rubber nursery management by the descriptive method.

\section{Results and Discussions}

\subsection{Socio-Demographic Characteristics of the Sample Respondents in the Study Areas}

The socio-demographic characteristics of the respondents in the studied area were shown in (Table 5). In the study area, the mean age of the sample respondents was 44.7 years. The youngest age of a farmer was 16, and the oldest was 74 . The ages between 36 to 60 gave the maximum response (75\%), and 16 to 35 years showed $17 \%$. The minimum $(8.3 \%)$ indicated 61 to 74 years.

According to the demographic data of the survey, $60 \%$ of the sample respondents were male, and $40 \%$ were female. In KMR township, $85 \%$ of farmers are male, and only $15 \%$ are female. These females are the farm leaders in rubber nursery management. More than half of the respondents from Mudon were male (60\%), and the rest were female (40\%). The opposite proportions were in TBZ. The majority (65\%) were female, and they also participated as the headed women in nursery operations. This study indicated that women could manage well in 
Table 5. Socio-demographic characteristics of the sampled respondents in the study area.

\begin{tabular}{|c|c|c|c|c|}
\hline Characteristics & $\begin{array}{l}\text { Kyaikmaraw } \\
\qquad(\mathrm{N}=20)\end{array}$ & $\begin{array}{l}\text { Mudon } \\
(\mathrm{N}=20)\end{array}$ & $\begin{array}{l}\text { Thanbyuzayat } \\
\qquad(\mathrm{N}=20)\end{array}$ & $\begin{array}{l}\text { Average } \\
(\mathrm{N}=60)\end{array}$ \\
\hline \multicolumn{5}{|l|}{ Gender (\%) } \\
\hline Male & 85 & 60 & 35 & 60 \\
\hline Female & 15 & 40 & 65 & 40 \\
\hline $\begin{array}{l}\text { Average age of } \\
\text { respondents (year) }\end{array}$ & $\begin{array}{c}42.10 \\
(16-67)\end{array}$ & $\begin{array}{c}48.40 \\
(30-74)\end{array}$ & $\begin{array}{c}43.60 \\
(29-67)\end{array}$ & $\begin{array}{c}44.70 \\
(16-74)\end{array}$ \\
\hline $\begin{array}{l}\text { Average nursery } \\
\text { experiences (years) }\end{array}$ & $\begin{array}{c}5.3 \\
(1-15)\end{array}$ & $\begin{array}{c}10.95 \\
(3-25)\end{array}$ & $\begin{array}{c}11.85 \\
(2-21)\end{array}$ & $\begin{array}{c}9.37 \\
(1-25)\end{array}$ \\
\hline \multicolumn{5}{|l|}{ Education in household (\%) } \\
\hline Primary school & 40 & 35 & 5 & 26.7 \\
\hline Middle school & 40 & 40 & - & 26.7 \\
\hline High school & 5 & 10 & 30 & 15 \\
\hline Graduated & 15 & 15 & 65 & 31.7 \\
\hline $\begin{array}{l}\text { Average family size } \\
\text { (person) }\end{array}$ & $\begin{array}{c}5.6 \\
(2-12)\end{array}$ & $\begin{array}{c}4.45 \\
(2-6)\end{array}$ & $\begin{array}{c}3.75 \\
(1-6)\end{array}$ & $\begin{array}{c}4.6 \\
(1-12)\end{array}$ \\
\hline $\begin{array}{l}\text { Average no. of family labor } \\
\text { (person) }\end{array}$ & $\begin{array}{c}3.15 \\
(1-7)\end{array}$ & $\begin{array}{c}1.65 \\
(1-4)\end{array}$ & $\begin{array}{c}2.10 \\
(1-4)\end{array}$ & $\begin{array}{c}2.3 \\
(2-7)\end{array}$ \\
\hline
\end{tabular}

Parentheses show minimum and maximum.

most rubber nurseries like men.

The average nursery experience was 9.37 years. Grower's experience (25 years) was maximum, and one year was the minimum. According to the survey data, most farmers (75\%) from KMR had nursery experience from 1 - 8 years. The rest $(25 \%)$ of respondents had a farming experience of 9 - 15 years. The nursery experience of farmers from Mudon, in the range of ( 9 - 15 years) was $40 \%$ after the range of $1-8$ years of $45 \%$. Nursery experience of 16 - 25 years showed the smallest percent (15\%). In TBZ, $40 \%$ of the respondents had 9 - 15 years of nursery experience. Then, the range of 1 - 8 years followed as $35 \%$. 25\% showed the minimum nursery experience of $16-25$ years. This result indicated that most respondents from Mudon and TBZ had a well-experience in nursery production compared with the respondents from KMR township. The majority of the respondents (65\%) from TBZ got a bachelor's degree, the respondents who completed high school education were $6 \%$, and only $15 \%$ of respondents finished their primary education. In KMR and Mudon, $15 \%$ of the respondents from each area showed as graduated people. A higher $40 \%$ each of these two townships completed middle school education. In the study areas, most respondents from TBZ were educated. 


\subsection{Farmer's Practices on Production of Rubber Seedling, Seedling Types and Use of Polybag Size}

(Table 6) showed farmer's practices on production of rubber seedlings in the study areas $(\mathrm{N}=60)$. The farmers in the study area produced an average of 12,700 seedlings on 0.26 ha. The maximum production of the seedlings was 60,000 , whereas the minimum was 3000 seedlings. In KMR township, most farmers possessed 0.2 ha to 0.4 ha of landholding, on which up to 20,000 seedlings could produce. $15 \%$ of the growers had more than 0.4 ha of landholding (over 20,000 seedlings). In Mudon township, 55\% of respondents grew under 10,000 seedlings, $35 \%$ by 10,000 - 20,000 seedlings, and $10 \%$ by more than 20,000 seedlings, respectively. Most of the respondents (50\%) from TBZ produced under 10,000 seedlings. In the case of nursery production, $100 \%$ of the respondents from KMR, 65\% from Mudon, and $80 \%$ from TBZ produced polybag seedlings. Concern with seedling types, production of polybag and budded-stump seedlings were from 35\% of growers from Mudon. From TBZ township, each of 5\% of respondents produced budded-stump, polybag and budded stump, polybag and seedlings, and polybag, budded-stump and seedling respectively. The majority of the respondents (80\%) from KMR and (90\%) from Mudon and (94.7\%) from TBZ used the polybag size of $15 \mathrm{~cm} \times 23 \mathrm{~cm}$.

Table 6. Farmer's practices on production of rubber seedlings in the study areas.

\begin{tabular}{|c|c|c|c|c|}
\hline Characteristics & $\begin{array}{l}\text { Kyaikmaraw } \\
\qquad(\mathrm{N}=20)\end{array}$ & $\begin{array}{l}\text { Mudon } \\
(\mathrm{N}=20)\end{array}$ & $\begin{array}{l}\text { Thanbyuzayat } \\
\qquad(\mathrm{N}=20)\end{array}$ & $\begin{array}{l}\text { Average } \\
(\mathrm{N}=60)\end{array}$ \\
\hline Number of rubber seedlings & \multicolumn{4}{|c|}{$\%$ of the respondents } \\
\hline$<10,000$ & 35 & 55 & 50 & 46.6 \\
\hline $10,000-20,000$ & 50 & 35 & 40 & 41.7 \\
\hline$>20,000$ & 15 & 10 & 10 & 11.7 \\
\hline Seedling types & \multicolumn{4}{|c|}{ Average number of seedlings } \\
\hline Polybag budded seedlings & $\begin{array}{c}13,900 \\
(3000-30,000)\end{array}$ & $\begin{array}{c}9100 \\
(4000-30,000)\end{array}$ & $\begin{array}{c}10,900 \\
(0-40,000)\end{array}$ & $\begin{array}{c}11,300 \\
(0-40,000)\end{array}$ \\
\hline Budded stump & - & $\begin{array}{c}3200 \\
(0-30,000)\end{array}$ & $\begin{array}{c}450 \\
(0-4000)\end{array}$ & $\begin{array}{c}1216 \\
(0-30,000)\end{array}$ \\
\hline Seedlings & - & - & $\begin{array}{c}550 \\
(0-6000)\end{array}$ & $\begin{array}{c}184 \\
(0-6000)\end{array}$ \\
\hline Polybag size & \multicolumn{4}{|c|}{$\%$ of the respondents } \\
\hline $15 \mathrm{~cm} \times 23 \mathrm{~cm}$ & 80 & 90 & 94.7 & 88.1 \\
\hline $15 \mathrm{~cm} \times 25 \mathrm{~cm}$ & 15 & - & 5.3 & 6.8 \\
\hline $13 \mathrm{~cm} \times 30 \mathrm{~cm}$ & 5 & - & - & 1.7 \\
\hline $14 \mathrm{~cm} \times 30 \mathrm{~cm}$ & - & 5 & - & 1.7 \\
\hline $15 \mathrm{~cm} \times 30 \mathrm{~cm}$ & - & 5 & - & 1.7 \\
\hline
\end{tabular}

Parentheses show minimum and maximum. 


\subsection{Farmers' Practice Using Compost in Growing Media}

Farmers' practice using compost in the growing medium for raising seedlings was shown in (Table 7). In the case of raising seedlings, most farmers in three areas $(40 \%, 50 \%, 55 \%)$ used soil and compost in growing media. Some growers (25\%) applied only soil in the growing medium, and the rest applied other materials such as burnt soil or animal manure mixed with soil for preparing growing media. Generally, most nursery producers use a mixture of sand and other materials as a growing medium.

This survey also pointed out that most farmers in the study sites used compost as the main component for preparing the growing medium. Only a few farmers prepared the medium with biochar and burnt soil.

\subsection{Farmers' Practice on Rubber Nursery Management}

(Table 8) shows some characteristics of farmers' practice on rubber nursery management. In the case of selecting the varieties, $80 \%$ of respondents used multi clone for stock. A few farmers (16.7\%) used BPM 24, and the other (3.3\%) used both multi-clones and BPM 24. For a seed source, 93.3\% of the seeds were from brokers. The others (3.3\%) were self-producing seeds, and the rest (3.3\%) received both ways. A basket of seed (including 3500 - 4500) cost an average of 12,100 kyats, and this price was different from 8000 kyats (minimum) to 24,000 kyats (maximum). Most respondents (78.3\%) selected BPM 24 as a scion in producing the budded seedlings. Each $1.7 \%$ of the respondents chose BPM 24 \& PB 235, BPM 24 \& PB 260, BPM 24, RRIT 251 \& RRIM 2000 series and BPM 24, RRIT 251, JV 80 \& KT 39/35 for budding. And the rest (15\%) was BPM 24 \& RRIT 251. The reasons for selecting different varieties were as follows: $86.7 \%$ of respondents supposed being the marketable varieties; $10 \%$ of respondents based on high latex yield; $1.7 \%$ based on each of capital and budding success. According to survey data, the budded plant (scion) of BPM 24 is the most popular among the farmers and followed by RRIT 251. The source of the scions was from brokers, private estates, government estate, and both broker \& private. The average cost of scion for one yard was 205 kyats, and the minimum \& maximum values were from 50 to 350 kyats.

Table 7. Farmers' practice using compost in growing media of the study areas.

\begin{tabular}{cccc}
\hline Components & $\begin{array}{c}\text { Kyaikmaraw } \\
(\mathrm{N}=20, \%)\end{array}$ & $\begin{array}{c}\text { Mudon } \\
(\mathrm{N}=20, \%)\end{array}$ & $\begin{array}{c}\text { Thanbyuzayat } \\
(\mathrm{N}=20, \%)\end{array}$ \\
Soil & 10 & 40 & 25 \\
Soil + compost & 40 & 50 & 55 \\
Soil + burnt soil & 20 & 5 & 10 \\
Soil + biochar & - & - & 5 \\
Soil + animal manure & 20 & - & - \\
Soil + compound & 10 & - & 5 \\
Soil + other & - & 5 &
\end{tabular}


Table 8. Characteristics of farmers' practice on nursery management in the study area (N $=60)$.

\begin{tabular}{|c|c|c|c|c|}
\hline \multirow{4}{*}{$\begin{array}{c}\text { No. } \\
1 \\
1\end{array}$} & \multirow{4}{*}{$\begin{array}{l}\text { Characteristics } \\
\text { Variety for stock }\end{array}$} & \multirow{2}{*}{$\begin{array}{l}\text { Categories } \\
\text { Multiclone }\end{array}$} & \multicolumn{2}{|c|}{ Frequency Respondents \% } \\
\hline & & & 48 & 80 \\
\hline & & BPM 24 & 10 & 16.7 \\
\hline & & Multiclone \& BPM 24 & 2 & 3.3 \\
\hline \multirow{3}{*}{2} & \multirow{3}{*}{ Source of stock } & Broker & 56 & 93.3 \\
\hline & & Collected & 2 & 3.3 \\
\hline & & Broker \& collected & 2 & 3.3 \\
\hline \multirow{2}{*}{3} & \multirow{2}{*}{$\begin{array}{c}\text { Cost of seeds } \\
\text { basket }^{-1} \text { (kyats) }\end{array}$} & $8000-12,000$ & 47 & 78.4 \\
\hline & & $13,000-24,000$ & 13 & 21.6 \\
\hline \multirow{6}{*}{4} & \multirow{6}{*}{ Variety for scion } & BPM 24 & 47 & 78.3 \\
\hline & & BPM $24 \&$ PB 235 & 1 & 1.7 \\
\hline & & BPM $24 \&$ PB 260 & 1 & 1.7 \\
\hline & & BPM 24, RRIT 251\& RRIM 2000 series & 1 & 1.7 \\
\hline & & BPM 24, RRIT 251, JV 80 \& KT 39/35 & 1 & 1.7 \\
\hline & & BPM 24 \& RRIT 251 & 9 & 15 \\
\hline \multirow{4}{*}{5} & \multirow{4}{*}{ Source of scion } & DOA & 3 & 5 \\
\hline & & Broker & 33 & 55 \\
\hline & & Private & 17 & 28.3 \\
\hline & & Broker \& Private & 7 & 11.7 \\
\hline \multirow{2}{*}{6} & \multirow{2}{*}{$\begin{array}{l}\text { Cost of scion } \\
\text { yard }^{-1} \text { (kyats) }\end{array}$} & $50-250$ & 49 & 81.7 \\
\hline & & $300-350$ & 11 & 18.4 \\
\hline \multirow{4}{*}{7} & \multirow{4}{*}{ Choice of variety } & Market & 52 & 86.7 \\
\hline & & High yield of latex & 6 & 10 \\
\hline & & Capital & 1 & 1.7 \\
\hline & & Budding success & 1 & 1.7 \\
\hline \multirow{2}{*}{8} & \multirow{2}{*}{ Budding time } & November-December & 5 & 8.3 \\
\hline & & January-February & 55 & 91.7 \\
\hline
\end{tabular}

Budding duration usually takes from November to February. In these months, $30 \%$ of the respondents from three regions faced constraints with the scions, and $16.7 \%$ had some requirements for each of stocks \& scions, and skilled labor of scion preparation. Some respondents $(20 \%)$ answered that there was no constraint. Locally, $60 \%$ of the respondents from KMR demanded the market. In addition, 20\% were from their required capital investment. A few (1\%) from each studied area received the constraint of water availability. The respondents of $95 \%$ from Mudon and $60 \%$ from TBZ had a market problem. (Table 9) shows some characteristics of farmers' practice on the fertilizer application in the study 
Table 9. Farmers' practices of fertilizer application in the study area.

\begin{tabular}{cccc}
\hline Characteristics & $\begin{array}{c}\text { Kyaikmaraw } \\
(\mathrm{N}=20)\end{array}$ & $\begin{array}{c}\text { Mudon } \\
(\mathrm{N}=20)\end{array}$ & $\begin{array}{c}\text { Thanbyuzayat } \\
(\mathrm{N}=20)\end{array}$ \\
\hline Type of fertilizer & 70 & 25 & 20 \\
Inorganic & 30 & 75 & 80 \\
\hline Inorganic \& organic & 7.14 & & 12.56 \\
\hline Rate of fertilizer (g.seedling $\left.{ }^{-1}\right)$ & $(0.3-25)$ & $(1-10)$ & $(1.9-50)$ \\
\hline Inorganic & 7.38 & 9.9 & 14.29 \\
\hline Organic & $(0-50)$ & $(0-50)$ & $(0-50)$ \\
\hline Frequency of fertilizer & & & 5.25 \\
\hline Inorganic & 4.5 & 6.10 & $(3-10)$ \\
\hline Organic & $(2-12)$ & $(3-16)$ & 3.8 \\
& 0.5 & 3.25 & $(0-10)$ \\
\hline
\end{tabular}

Parentheses show minimum and maximum.

areas. The majority of the respondents from KMR used inorganic fertilizer, and the rest (30\%) used organic and inorganic fertilizer. In inorganic fertilizer, 70\% of the respondents used the compound type; the other (15\%) used the straight. The last 15\% used both compound and straight fertilizer. In contrast with KMR, most respondents (75\%) from Mudon applied organic and inorganic fertilizer to their rubber nurseries. Other respondents (25\%) used only inorganic fertilizer. In inorganic fertilizer, $70 \%$ of the farmers used types, compound \& straight fertilizer. In particular, $25 \%$ of the respondents used compound fertilizer, and the rest (5\%) used straight fertilizer. In TBZ, the majority (80\%) of the respondents used both organic and inorganic fertilizer for their rubber nurseries, and only $20 \%$ used inorganic fertilizer. The respondents of $75 \%$ used compound fertilizer, $20 \%$ used both organic and inorganic fertilizer. The rest of the farmers (5\%) used straight fertilizer. In the study areas, most of the farmers used both organic and inorganic fertilizers. And, organic fertilizer is as important as inorganic fertilizer in the rubber nursery.

\subsection{Characterization of Some Constraints on Using Compost in Growing Media}

Respondents from KMR township, $40 \%$ used compost as a component of growing media. Among them, $62.5 \%$ of farmers purchase compost for their potting soil, and $37.5 \%$ made compost themselves by using the pile method. All respondents used yard waste (a mixture of grasses and various dry leaves). The respondents of $33.3 \%$ used cow dung manure in composting $66.7 \%$ composted only yard wastes (Table 10). 
Table 10. Characterization of some constraints using compost in growing medium.

\begin{tabular}{ccccc}
\hline Characteristics & $\begin{array}{c}\text { Kyaikmaraw } \\
(\mathrm{N}=20)\end{array}$ & $\begin{array}{c}\text { Mudon } \\
(\mathrm{N}=20)\end{array}$ & $\begin{array}{c}\text { Thanbyuzayat } \\
(\mathrm{N}=20)\end{array}$ & $\begin{array}{c}\text { Average } \\
(\mathrm{N}=60)\end{array}$ \\
\hline Use of compost & 40 & 50 & 55 & 45 \\
Yes & 60 & 50 & 45 & 55 \\
No & - & $\%$ of the respondents & \\
\hline Use of raw materials $(\mathrm{RM})$ & 100 & 10 & - & 4.3 \\
\hline Grasses & & 90 & 100 & 95.7 \\
Yard waste & 48 & 355 & 162.5 & 197.3 \\
\hline Amount of compost & $-150)$ & $(100-750)$ & $(25-450)$ & $(10-750)$ \\
\hline Constraints & - & $\%$ of the respondents & \\
\hline Nil & 90 & 15 & 5 & 6.7 \\
Composting method & - & 85 & 80 & 85 \\
Availability of raw materials & - & - & 10 & 3.3 \\
Land requirement & 10 & - & 5 & 1.7 \\
The scarcity of time & & & - & 3.3 \\
\hline
\end{tabular}

Parentheses show minimum and maximum.

In Mudon, $50 \%$ of the growers used compost, and $40 \%$ used only soil as growing media. All the respondents who used the compost in growing media obtained compost by making themselves. Within the growers, $90 \%$ used yard waste as the raw materials for composting. The other respondents (10\%) used only grasses for composting. There was $70 \%$ of farmers used poultry manure (PM) in composting, and the others did not use PM.

From the data of TBZ, $55 \%$ of farmers used compost as components of growing media in potting soil, $5 \%$ used only soil, and the rest used burned soil or biochar to mix with soil. All the respondents (100\%) from TBZ used yard waste in composting by using the pile method. Most of them (50\%) mixed burned soil with yard waste in composting, and $10 \%$ used cow dung as a component of composting. The other $40 \%$ used only yard waste in composting.

The mean value of compost application rate from the studied areas was 197.3 $\mathrm{g}$ per seedling. The minimum amount of compost was $10 \mathrm{~g}$ per seedling, and the maximum amount of compost used by farmers was $750 \mathrm{~g}$ per seedling. In KMR, most farmers $(87.5 \%)$ used compost of less than $100 \mathrm{~g}$ per seedling. The remainder of $12.5 \%$ used $150 \mathrm{~g}$ per seedling. The minimum amount of compost used in the respondents from Mudon was $100 \mathrm{~g}$ per seedling, and the maximum amount was $750 \mathrm{~g}$ per seedling. The mean value was $355 \mathrm{~g}$ per seedling. The farmers who used the compost at the rate of less than $100 \mathrm{~g}$ per seedling were $63.7 \%$. The other $18.2 \%$ used 100 - $300 \mathrm{~g}$ per seedling, and the rest $18.2 \%$ used $>300 \mathrm{~g}$ per seedling. 
Concern with composting, most respondents (90\%) from KMR faced how to prepare the compost properly, and the rest (10\%) had no time for composting. In the future, $80 \%$ of farmers wanted to attend the compost training, and the rest had no desire. Similarly, most respondents from Mudon had constraints for composting method. Although they knew the benefit of compost application, $65 \%$ wanted to attend the training for composting. In TBZ, $80 \%$ of respondents also faced constraints concerning the composting method. Lesser percent (10\%) of farmers did not receive the raw materials properly, and the other $5 \%$ had the problem of land availability for composting. A few (5\%) did not have any constraints. In the future, $90 \%$ also desired to attend the composting training. Generally, the compost users from these three sites knew the benefits of using compost. Composting encourages plant growth, improves soil fertility, and helps to retain water.

\section{Conclusion}

This survey made a strategic plan to assess the farming practices to provide rubber nursery production in Myanmar. As the results of respondents from all three-survey areas, most producers were middle age group of (36 - 60) years. This indicator showed that farmers were potentially active operators in rubber nursery production. Based on field experience, nursery management was locally different. Almost all farmers used the polybag with $15 \mathrm{~cm} \times 23 \mathrm{~cm}$ size for raising the budded seedlings. In selecting rubber varieties, most growers used multi-clonal seeds for stocks and BPM 24 for scions due to the local market demand and latex yield. To raise budded seedlings, half of the respondents used compost as a component of growing media. For composting, most local farmers prepared themselves, and some purchased. Thus, almost all farmers had some constraints with the proper composting method and high demand for compost. Moreover, they wanted to receive the pieces of training for composting. All survey areas used organic and inorganic fertilizers for nutrient management in nursery productions. In sum, this study exposed some local constraints and suggested improving the proper composting method for rubber nursery establishment.

\section{Acknowledgements}

I wish my heartfelt appreciation went to everyone who supported me during my studies, one way or another. I never forget their guidance and kind support of Dr. Nyein Nyein Htwe, Professor and Head of the Department of Extension at Yezin Agricultural University, U Tun Tun Htwe, Director and Head, Perennial Crops Division (PCD), DOA, U Kyi Soe, Director (retired), all staff and respondent farmers from Mudon, Thanbyuzayat, and Kyaikmaraw Townships.

\section{Conflicts of Interest}

The authors declare no conflicts of interest regarding the publication of this paper. 


\section{References}

[1] Ministry of Agriculture, Livestock and Irrigation (2018) Myanmar Agriculture at a Glance.

[2] Ministry of Agriculture, Livestock and Irrigation (2020) Myanmar Agriculture at a Glance.

[3] National Export Strategy (2019) Rubber Sector Strategy, 2015-2019. https://www.myantrade.org/files/

[4] Department of Agriculture, Mon State (2020) Annual Report. Department of Agriculture, Ministry of Agriculture, Livestock and Irrigation, Mon State, Myanmar..

[5] Zaw, Z.N. and Myint, H. (2016) Common Agricultural Practices and Constraints of Natural Rubber Industry in Myanmar. Songklanakarin Journal of Plant Science, 3, 1-8.

[6] Department of Agriculture (2017) Establishment of Rubber Nursery, Office No. 50, Nay Pyi Taw, Perennial Crop Division, Department of Agriculture, Ministry of Agriculture, Livestock and Irrigation, Nay Pyi Taw.

[7] Orimoloye, J.R., Ugwa, I.K. and Idoko, S.O. (2010) Soil Management Strategies for Rubber Cultivation in an Undulating Topography of Northern Cross River State. Journal of Soil Science and Environmental Management, 1, 34-39.

[8] Waizah, Y., Uzu, F.O., Orimoloye, J.R. and Idoko, S.O. (2011) Effects of Rubber Effluent, Urea and Rock Phosphate on Soil Properties and Rubber Seedlings in an Acid Sandy Soil. African Journal of Agricultural Research, 6, 3733-3739.

[9] Department of Agriculture, Mon State (2021) Annual Report. Department of Agriculture, Ministry of Agriculture, Livestock and Irrigation, Mon State, Myanmar.

[10] Ministry of Immigration and Population (2015) The 2014 Myanmar Population and Housing Census Mon State.

[11] Department of Agricultural land Management \& Statistics (2020) Annual Report. Department of Agriculture, Ministry of Agriculture, Livestock and irrigation, Nay Pyi Taw. 